\title{
Silage yield, organic carbon content and physical attributes of a chiseled Ferralsol under an integrated crop-livestock system
}

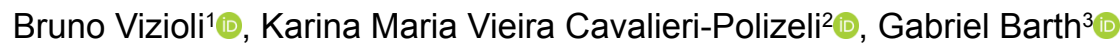 \\ ${ }^{1}$ Centro Universitário do Vale do Iguaçu, Uniguaçu, Núcleo de Práticas Agronômicas, União da Vitória, PR, Brazil. E-mail: brunovizioli@gmail.com \\ 2 Universidade Federal do Paraná, Departamento de Solos e Engenharia Agrícola, Curitiba, PR, Brazil. E-mail: karina.cavalieri@ufpr.br \\ ${ }^{3}$ Fundação ABC para Assistência e Divulgação Técnica Agropecuária, Setor de Solos e Nutrição de Plantas, Castro, PR, Brazil. E-mail: gabrielbarth@fundacaoabc.org.br
}

ABSTRACT: The aim of this study was to evaluate the physical attributes and the silage production of a soil submitted to chiseling under an integrated crop-livestock system (ICLS) for nine years. The experiment was performed with clayey Ferralsol with three treatments (no-tillage, no-tillage with chiseling every other year, and conventional tillage) and three blocks. Corn was grown for silage in the summer, and ryegrass for pasture in the winter. The sampled soil layers each year were: 0.00-0.05 m; 0.05-0.10 $\mathrm{m} ; 0.10-0.20 \mathrm{~m}$; and $0.20-0.30 \mathrm{~m}$, in order to determine total organic carbon, particle density, texture, porosity, bulk density and resistance to penetration. Compaction was evaluated by the relative density and the structure by the structural index. Dry matter corn silage yield and ryegrass forage were determined. Chiseling did not provide higher silage yield compared to other treatments. However, chiseling provided improvements in the physical attributes of the Ferralsol conducted over nine years on ICLS with the physical attributes of the soil detected 12 months after chiseling management.

Key words: conventional tillage; integrated agricultural production systems; no-tillage; physical soil quality

\section{Produção de silagem, teor de carbono orgânico e atributos físicos de Latossolo escarificado sob integração lavoura-pecuária}

RESUMO: O objetivo do estudo foi avaliar os atributos físicos e a produção de silagem de um solo conduzido há nove anos com escarificação sob sistema integrado de produção agropecuária (SIPA). 0 experimento foi realizado em um Latossolo Bruno distrófico típico argiloso com três tratamentos (plantio direto; plantio direto com escarificação a cada dois anos e preparo convencional) e três blocos. No verão era cultivado milho para a produção de silagem e no inverno era semeado azevém para pastejo. Aos noves anos da implantação foram amostradas as camadas: 0,00-0,05; 0,05-0,10; 0,10-0,20 e 0,20-0,30 m, para a determinação de carbono orgânico total, densidade de partículas, textura, porosidade, densidade do solo e resistência à penetração. A compactação foi avaliada pela densidade relativa e a estrutura pelo índice estrutural. Foram determinadas as produtividades de silagem de milho e a oferta de forragem do azevém. Embora a escarificação não tenha proporcionado aumento na produtividade de silagem de milho, comparada aos demais tratamentos, proporcionou melhorias nos atributos físicos do Latossolo Bruno conduzido por nove anos em SIPA, efeito detectado 12 meses após o manejo.

Palavras-chave: preparo convencional; sistemas integrados de produção agropecuária; plantio direto; qualidade física do solo 


\section{Introduction}

Integrated crop-livestock systems (ICLS) have been highlighted in the scenario of modern Brazilian agriculture, since they provide low economic risk economic to farmers (Moraes et al., 2014a). In addition, there are many benefits of ICLS to the soil such as carbon input (Costa et al., 2015; Piano et al., 2015), soil structure improvement (Piano et al., 2015) and potential productivity gains (Moraes et al., 2014a). Thus, ICLS is almost exclusively adopted by the producers in the Campos Gerais-Paraná-Brazil region (Santos et al., 2018b). In this region, ryegrass (Lolium multiflorum Lam.) is cultivated and grazed during the winter and corn (Zea mays L.) is grown in the summer for silage yield (Santos et al., 2018b). The crops are usually cultivated under a no-tillage system, which is the most used in the region (Moraes et al., 2014a; Santos et al., 2018b).

We know of the advantages that a no-tillage system brings to soils (Kunz et al., 2013). However, due to the absence of tillage, it is possible that no-tillage can cause some damage to soil physical attributes (Lozano et al., 2016), especially if it is associated with animal trampling and under crop succession. Trampling is reported as one of the main compaction agents of soils when performed in inadequate conditions (Kunz et al., 2013).

Therefore, in order to avoid the compaction that notillage causes on the soil and to continue using the ICLS, some farmers adopt a conventional tillage system. This system revolves (tills) the soil and disaggregates its structure, thereby facilitating root system development of the plants in the first $0.20 \mathrm{~m}$ of depth. A disadvantage is compacting the layer below the working depth of agricultural equipment, as well as promoting soil carbon and nutrient losses through erosion. Thus, an intermediary to no-tillage and conventional tillage systems is the periodic chiseling of soils under notillage (Lozano et al., 2016). This preparation has the potential to break any compacted layers resulting from no-tillage, but does not till the soil, favoring its structure and porosity over time (Drescher et al., 2016; Calonego et al., 2017).

Chiseling has been used in soils under crop use (Allmaras et al., 1977; Moraes et al., 2014b; Drescher et al., 2016; Calonego et al., 2017), with beneficial results to the soil physical attributes (Allmaras et al., 1977; Calonego et al., 2017), but few studies have been performed with soils under ICLS that evaluate the effect of chiseling on physical attributes. Drescher et al. (2016) concluded that the effect of chiseling on bulk density and macroporosity was ephemeral and inferior to an agricultural crop (about six months) in Rhodic Ferrasol under crop rotation. However, the authors observed that the effect of chiseling on the hydraulic conductivity, transport and water retention of that soil could be detected for up to two years. Calonego et al. (2017) also observed that chiseling improved the physical attributes of a Nitosol under crop rotation.

According to Calonego et al. (2017) and Reichert et al. (2017), the need to chisel soils under no-tillage is debatable, because when the soils are managed with a great diversity of plants in both cultivation crop use and in ICLS, the soils do not present limiting conditions to vegetal development. Thus, in ICLS in which there are successions of two plant species in the crops, the idea that no-tillage would maintain favorable conditions to plant development may not be valid, since there is no plant diversity. In addition, there is animal trampling, in which case chiseling could improve the physical attributes of the soil for plant growth and development.

The hypothesis of this work was that the periodic chiseling of the soil on ICLS may promote an increase in silage yield by improving the carbon organic content and physical attributes of the soil. Therefore, the objective of this work was to evaluate the silage yield, carbon organic content and physical attributes in a soil under different tillage systems in an integrated croplivestock system conducted over nine years.

\section{Materials and Methods}

The data are provided from an experiment started in March 2005 , and the results presented in this study correspond to an evaluation in May 2014, nine years after the beginning of the experiment. The studied soil is a Humic Ferralsol, "Latossolo Bruno Distrófico típico" (Santos et al., 2018a) with clayey texture (Table 1), located in the municipality of Castro-PR-

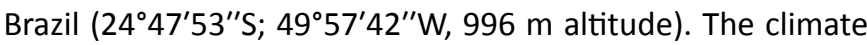
is $\mathrm{Cfb}$ temperate humid with frost occurring in winter. The average maximum temperature during the year is $25 \circ \mathrm{C}$, and the average minimum is 5 으 (Alvares et al., 2013).

The soil of the area was under native vegetation until the year 1960; from that date a conversion occurred to cultivation with the planting of wheat (Triticum sativum L.) in the winter crop and soybean (Glycine max [L.] Merril) in the summer crop. The wheat-soybean succession occurred in the area under conventional tillage (a plowing and two harrowings in the 0.00-0.20 m layer) until March 2005, when the experiment started. In March 2005 the soil was tilled up to approximately $0.20 \mathrm{~m}$ to eliminate the crop residues of the previous harvests. At this time, 5,360 $\mathrm{kg} \mathrm{ha}^{-1}$ of dolomitic limestone was applied to the soil and 8,360 $\mathrm{kg} \mathrm{ha}^{-1}$ was then reapplied in March 2009 as indicated by chemical analysis. From the beginning of the experiment there was crop succession with annual ryegrass for pasture during winter season and corn silage in the summer.

The experiment was a randomized complete block design with three treatments repeated and three blocks. The treatments were soil tillage systems on ICLS: no-tillage; notillage with chiseling every other year and conventional tillage. Each plot occupied an area of $100 \mathrm{~m}^{2}(10 \times 10 \mathrm{~m})$. In the notillage treatment, the soil was not revolved, but seedling rows for seed deposition; in the no-tillage with chiseling treatment, the soil was maintained without any tilling, but mechanical chiseling was carried out to the depth of $0.30 \mathrm{~m}$ every other year with $0.60 \mathrm{~m}$ spacing between the chisel-type rods. The chiseling occurred in the years 2007, 2009, 2011 and 2013, before ryegrass planting. In the third treatment, the soil was conventional tillage with a disc plow in the depth up to 0.20 
Table 1. Textural composition and particle density $\left(\rho_{p}\right)$ of the Ferralsol under crop-livestock integration, with different soil tillage.

\begin{tabular}{|c|c|c|c|c|c|}
\hline \multirow{2}{*}{ Treatment } & Clay & Silt & Coarse Sand ${ }^{1}$ & Fine Sand ${ }^{1}$ & \multirow{2}{*}{$\begin{array}{c}\rho_{p} \\
\mathrm{~kg} \mathrm{dm^{-3 }}\end{array}$} \\
\hline & \multicolumn{4}{|c|}{$\mathrm{g} \mathrm{kg}^{-1}$} & \\
\hline & \multicolumn{4}{|c|}{$0.00-0.05 \mathrm{~m}$} & \\
\hline No-tillage & 472 & 96 & 319 & 113 & 2.51 \\
\hline Chiseling & 446 & 122 & 317 & 115 & 2.54 \\
\hline \multirow[t]{2}{*}{ Conventional Tillage } & 471 & 117 & 303 & 110 & 2.54 \\
\hline & \multicolumn{4}{|c|}{$0.05-0.10 \mathrm{~m}$} & \\
\hline No-till & 488 & 114 & 298 & 100 & 2.54 \\
\hline Chiseling & 401 & 120 & 291 & 119 & 2.60 \\
\hline \multirow[t]{2}{*}{ Conventional Tillage } & 457 & 130 & 309 & 105 & 2.52 \\
\hline & \multicolumn{4}{|c|}{$0.10-0.20 \mathrm{~m}$} & \\
\hline No-tillage & 514 & 102 & 285 & 99 & 2.56 \\
\hline Chiseling & 494 & 100 & 299 & 107 & 2.58 \\
\hline \multirow[t]{2}{*}{ Conventional Tillage } & 510 & 99 & 288 & 103 & 2.51 \\
\hline & \multicolumn{4}{|c|}{$0.20-0.30 \mathrm{~m}$} & \\
\hline No-tillage & 528 & 97 & 276 & 99 & 2.55 \\
\hline Chiseling & 513 & 97 & 292 & 98 & 2.55 \\
\hline Conventional Tillage & 546 & 90 & 269 & 95 & 2.53 \\
\hline
\end{tabular}

${ }^{1}$ The classification of Coarse Sand and Fine Sand according to the Brazilian Soil Science Society (SBCS), in which Coarse Sand: 2-0.2 mm and Fine Sand $=0.2-0.053 \mathrm{~mm}$.

$\mathrm{m}$ and two harrows with leveling grades up to $0.10 \mathrm{~m}$ depth were applied before planting each crop.

Crop planting occurred annually in May (ryegrass pasture) and in October (corn silage). The ryegrass seeding rate was 60 $\mathrm{kg} \mathrm{ha}^{-1}$ sown at a depth of $0.03 \mathrm{~m}$ and $0.17 \mathrm{~m}$ row spacing. For corn, $20 \mathrm{~kg} \mathrm{ha}^{-1}$ of seeds sown at a depth of $0.03 \mathrm{~m}$ and 0.80 $\mathrm{m}$ row spacing. A no-tillage seeder was used for both crops. The ryegrass cultivar used in 2013 was FABC 1 , and the corn hybrid P30R50 in the 2013/14 crop. At ryegrass planting time, $200 \mathrm{~kg} \mathrm{ha}^{-1}$ of fertilizer $10-20-10\left(\mathrm{~N}-\mathrm{P}_{2} \mathrm{O}_{5}-\mathrm{K}_{2} \mathrm{O}\right)$ was applied and $120 \mathrm{~kg} \mathrm{ha}^{-1}$ urea covering and $36 \mathrm{~kg} \mathrm{ha}^{-1}$ potassium (potassium chloride $-\mathrm{KCl}$ ) in the tillering phase of the crop. The corn received $165 \mathrm{~kg} \mathrm{ha}^{-1}$ of $\mathrm{N}$ (ureia souce), with the first part of planting time with $40 \mathrm{~kg} \mathrm{ha}^{-1}$ of the 15-30-0 fertilizer $\left(\mathrm{N}-\mathrm{P}_{2} \mathrm{O}_{5}-\mathrm{K}_{2} \mathrm{O}\right)$ formulation, and the remainder applied at the V4 crop stage with 25-00-25 fertilizer. At the planting time, $80 \mathrm{~kg} \mathrm{ha}^{-1}$ of $\mathrm{P}_{2} \mathrm{O}_{5}$ and $125 \mathrm{~kg} \mathrm{ha}^{-1}$ of $\mathrm{K}_{2} \mathrm{O}$ were applied to the sowing line. Weeds were controlled by nicosulforon, a postemergent herbicide $\left(600 \mathrm{~g} \mathrm{ha}^{-1}\right)$ at the V 3 crop stage. The corn was harvested for silage at the beginning of the flowering in February. The ryegrass was grazed during in winter when plants reached $0.30 \mathrm{~m}$ height for Dutch dairy cattle $(1350 \mathrm{~kg}$ ha $^{-1}$ stock). The cows remained in the plots for about seven days or until the ryegrass residue reached a height of less than $0.10 \mathrm{~m}$. Cattle returned to graze when ryegrass reached again a height of $0.30 \mathrm{~m}$. The ryegrass residue was sprayed with Glyphosate $\left(1,200 \mathrm{~g} \mathrm{ha}^{-1}\right)$ before planting the corn. The corn succession for silage and ryegrass pasture happened from May 2005 until May 2014 when the trial finished.

After the corn harvest in May 2014, the soil was sampled in layers of $0.00-0.05 \mathrm{~m} ; 0.05-0.10 \mathrm{~m} ; 0.10-0.20 \mathrm{~m}$ and $0.20-0.30$ $\mathrm{m}$, where three undisturbed and disturbed soil samples were collected per plot in each layer. The undisturbed samples were collected in volumetric metal cylinders $(0.05 \mathrm{~m}$ high $\times 0.045$ $\mathrm{m}$ wide) in the corn sowing row at three points of the plot area. The soil surplus of the cylinder comprised the disturbed soil samples, totaling 108 samples. It is worth mentioning that the data presented correspond to the soil sampling in 2014, twelve months after the last chiseling occurred in 2013; and six months after the conventional tillage that occurred before sowing of each crop.

The soil texture was determined by the Bouyoucus densimeter method and the particle density $\left(\rho_{p}\right)$ by the modified volumetric flask method (Table 1). The total organic carbon content (TOC) was determined by the Walkley-Black method (Walkley \& Black, 1934).

The undisturbed samples were prepared in the laboratory and saturated with water, raising a water slide in $2 / 3$ of the cylinder height for 36 hours; the wet mass was measured after saturation, and then submitted to the potential of -100 $\mathrm{hPa}$ in Richards chamber (Richards, 1965). The wet mass of the samples was again measured after reaching hydraulic equilibrium at the potential, and the samples were subjected to the penetration resistance (PR) test using a bench-top penetrometer with a 4-mm diameter cone tip, angle of $60^{\circ}$ to a velocity of $0.001 \mathrm{~m} \mathrm{~s}^{-1}$. Obtaining the mean PR data from each sample followed the procedures described in Tormena et al. (1998). After determining PR, the samples were dried in a forced air circulation oven for $36 \mathrm{~h}$ at $105^{\circ} \mathrm{C}$. Bulk density $\left(\rho_{B}\right)$ was obtained from the ratio of the dry soil mass $(\mathrm{kg})$ by volume of the metal cylinder $\left(\mathrm{dm}^{3}\right)$. Total porosity (TP) was obtained from the water volume ratio saturated by the volume of the metal cylinder, the microporosity (MI) was equivalent to the soil water volume after the hydraulic equilibrium at the pressure of $-100 \mathrm{hPa}$ and macroporosity (MA) through the difference between TP and MI.

Using the texture and TOC data, the maximum soil density $\left(\rho_{M}\right)$ was estimated by the pedotransfer function proposed by Marcolin \& Klein (2011), in which: $\rho_{M}=2.03133855$ $0.00320878 *\left(\right.$ TOC$\left.^{*} 1.724\right)-0.00076508 *$ Clay. Then using the $\rho_{M}$ data, the soil relative density $\left(\rho_{R}\right)$ could be estimated by the formula $\rho_{R}=\rho_{B} / \rho_{M}$.

Soil structure was evaluated by the soil structural index (SI) as proposed by Reynolds et al. (2009): SI = [(TOC*1.724)/ 
$\left(\right.$ Clay+Silt) ${ }^{*} 100$; in which the TOC is in $\mathrm{g} \mathrm{dm}^{-3}$, and the clay and silt in $\mathrm{g} \mathrm{kg}^{-1}$.

The available water content (AW), which equals the difference between the water content in the field capacity and the permanent wilting point, respectively associated with the potential values of -100 and $-15000 \mathrm{hPa}$, was given by the soil water retention curve (SWRC) estimated for each undisturbed sample using the SPLINTEX pedotransfer function proposed by Prevedello \& Loyola (2002) and validated by Silva et al. (2017). The SPLINTEX pedofunction estimates the parameters $\theta_{R^{\prime}} \alpha, n$ and $m$ (Table 2 ) of the van Genuchten (1980) equation, from the texture data (clay, silt, coarse sand and fine sand), $\rho_{\rho}$, $\rho_{B}$ and a measured moisture value, in this case the moisture to the pressure of $-100 \mathrm{hPa}$, considered by Silva et al. (2017) as the value that obtains the best estimates of the parameters.

The average yield of each treatment was obtained from the dry matter mass of corn and ryegrass harvested in the useful area of each plot. In the case of corn, the production of silage and ryegrass was considered to be the forage supply before cattle grazing.

TOC, $\rho_{B^{\prime}} \rho_{R^{\prime}} \mathrm{MA}, \mathrm{MI}, \mathrm{TP}, \mathrm{WA}, \mathrm{SI}$, and crop yield data were submitted to the Shapiro-Wilk normality test and analysis of variance, and the means were compared by the Duncan test when they were significant by the F-test $(p<0.05)$.

\section{Results and Discussion}

The treatments promoted differences in TOC content, and the chiseling presented the highest TOC content in relation to no-tillage in all the evaluated layers. No-tillage and Conventional tillage had the same statistical TOC values in the 0.00-0.05 and 0.20-0.30 m layers, but lower than chiseling (Table 3). The TOC was higher in the Conventional tillage in relation to No-tillage in the $0.05-0.10$ and $0.10-0.20$ m layers, probably due to the rotation that incorporates vegetal material to depth of work $(0.20 \mathrm{~m})$. The lower TOC content in the surface layer under no-tillage contrasts with what has been reported in the literature, in which the highest TOC values are determined in topsoil layers under no-tillage (Piva et al., 2012; Olson et al., 2016). Olson et al. (2016) verified a higher TOC content in the no-tillage treatment in the A horizon of a claysilty soil conducted under crop succession (soybean-corn) in a no-tillage system, no-tillage with chiseling and conventional tillage in the United States. The authors attributed the results to plant materials with different compositions. However, the plant material present in the soil studied herein consisted exclusively of grasses with slower degradation, which may have influenced the results.

The benefit of chiseling in increasing TOC content in relation to no-tillage is attributed to incorporating plant material into the soil every other year, four times in nine years of study. This plant material is generally coarser than plant material incorporated in the conventional tillage, which favors the slow and gradual decomposition of the residue incorporated by the chiseling (Olson et al., 2016; Seben Junior et al., 2016). Chiseling does not fully expose the compost/residue to microorganism action and oxygen which accelerates the degradation process, and which usually occurs in conventional tillage, favoring the results observed in this treatment in the 0.00-0.05 m layer. Another characteristic of chiseling is to break up the topsoil layer, facilitating root development at depth (Colussi et al., 2014). As is known, the roots are the main sources of TOC in depth (Shahbaz et al., 2017). On the other hand, there was greater immobilization and preservation of the residue in no-tillage, and consequently lower decomposition and TOC release. Moreover, the management did not favor root growth in depth, which provided a lower content in this layer.

Incorporating more fragmented plant residues in tillage systems that revolve the soil favored an increase of TOC in deeper layers (Shahbaz et al., 2017). Tilling also favors increased air and water flow in depth, promoting the growth of more roots (Shahbaz et al., 2017). These findings are in

Table 2. Mean of the fit parameters of the van Genuchten (1980) equation estimated by the SPLINTEX pedotransfer function.

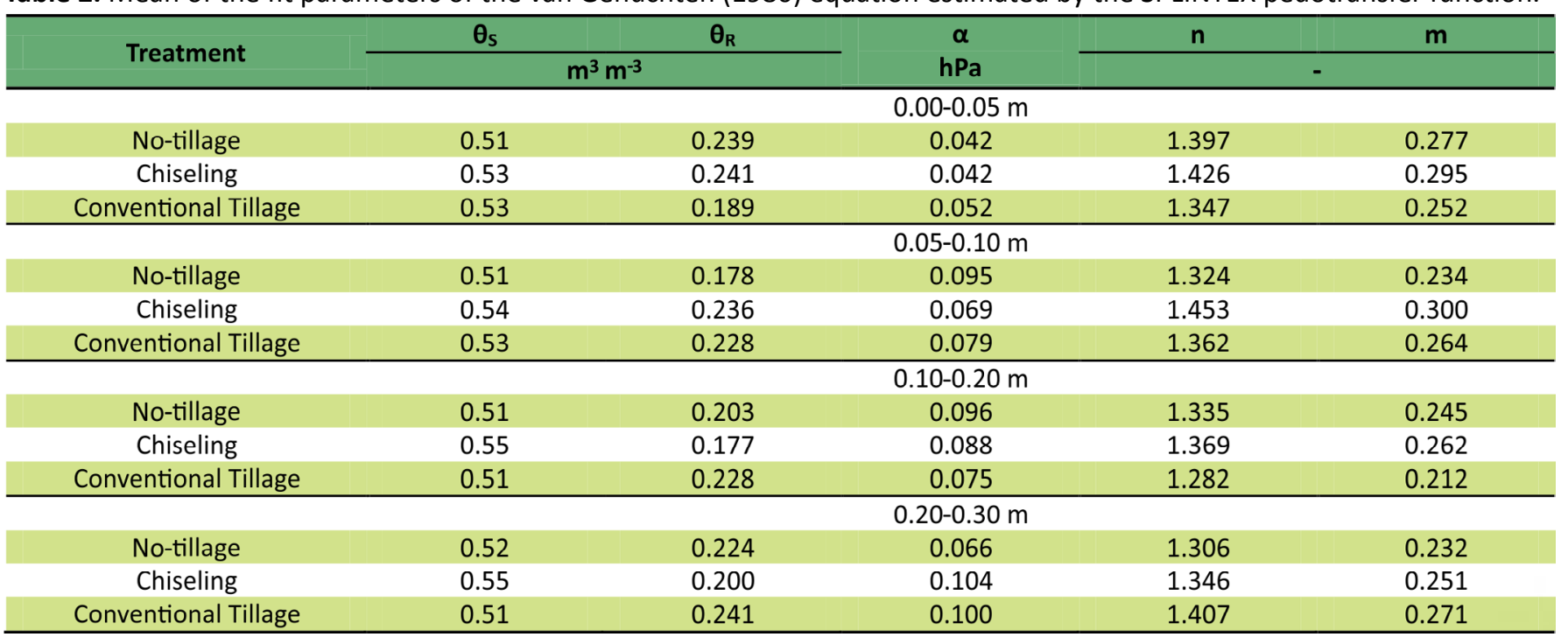

$\theta_{s}=$ volumetric water content $\left(\mathrm{m}^{3} \mathrm{~m}^{-3}\right) ; \theta_{R}=$ residual water content $\left(\mathrm{m}^{3} \mathrm{~m}^{-3}\right) ; \alpha=$ empirical parameter which is often referred to as the inverse of the air entry point (hPa); $n=$ the soil water characteristic curve index (shape parameter of the curve); $m=1-1 / n$. 
Table 3. Mean values of total organic carbon (TOC); soil bulk density $\left(\rho_{B}\right)$; relative soil bulk density $\left(\rho_{R}\right)$; macroporosity (MA); microporosity (MI), total porosity (TP); water available (WA) and structural index (SI) of a Ferralsol under crop-livestock integration, with different soil tillage.

\begin{tabular}{|c|c|c|c|c|c|c|c|c|}
\hline \multirow{2}{*}{ Treatment } & \multirow{2}{*}{$\begin{array}{c}\text { TOC } \\
\left(\mathrm{g} \mathrm{dm}^{-3}\right)\end{array}$} & \multirow{2}{*}{\multicolumn{2}{|c|}{\begin{tabular}{c}
$\rho_{B} \quad \rho_{R}$ \\
\multicolumn{2}{c|}{$\left(\mathrm{kg} \mathrm{dm}^{-3}\right)$}
\end{tabular}}} & MA & MI & TP & WA & \multirow{2}{*}{$\begin{array}{l}\text { SI } \\
(\%)\end{array}$} \\
\hline & & & & \multicolumn{4}{|c|}{$\left(m^{3} m^{-3}\right)$} & \\
\hline \multicolumn{9}{|c|}{$0.00-0.05 \mathrm{~m}$} \\
\hline No-tillage & $43.87 b$ & $1.32 \mathrm{a}$ & 0.81 & 0.10 & 0.41 & 0.51 & 0.15 & 13.33 \\
\hline Chiseling & $52.31 a$ & $1.24 b$ & 0.82 & 0.11 & 0.42 & 0.53 & 0.16 & 14.26 \\
\hline Conventional Tillage & $48.4 a b$ & $1.25 b$ & 0.87 & 0.11 & 0.42 & 0.53 & 0.14 & 15.71 \\
\hline CV (\%) & 11.09 & 8.21 & 8.50 & 32.53 & 12.29 & 9.53 & 7.96 & 14.06 \\
\hline $\mathrm{F}$ & $5.61^{*}$ & $1.39^{*}$ & $1.62^{\text {ns }}$ & $0.24^{\mathrm{ns}}$ & $0.16^{\mathrm{ns}}$ & $0.59^{\text {ns }}$ & $0.33^{\text {ns }}$ & $1.05^{\text {ns }}$ \\
\hline \multicolumn{9}{|c|}{$0.05-0.10 \mathrm{~m}$} \\
\hline No-tillage & $31.70 b$ & $1.37 a$ & $0.87 a$ & $0.10 \mathrm{~b}$ & 0.41 & 0.51 & 0.11 & 8.80 \\
\hline Chiseling & 39.13a & $1.29 b$ & $0.84 a b$ & $0.14 a$ & 0.40 & 0.54 & 0.12 & 11.61 \\
\hline Conventional Tillage & $36.33 a$ & $1.29 b$ & $0.83 b$ & $0.11 a b$ & 0.42 & 0.53 & 0.13 & 10.71 \\
\hline $\mathrm{CV}(\%)$ & 8.79 & 5.33 & 5.86 & 26.70 & 10.40 & 6.57 & 8.96 & 13.97 \\
\hline $\mathrm{F}$ & $12.85^{*}$ & $3.37^{*}$ & $2.72^{*}$ & $2.76^{*}$ & $0.31^{\text {ns }}$ & $0.94^{\text {ns }}$ & $0.68^{\text {ns }}$ & $2.93^{\text {ns }}$ \\
\hline \multicolumn{9}{|c|}{$0.10-0.20 \mathrm{~m}$} \\
\hline No-tillage & $28.70 \mathrm{~b}$ & 1.31 & 0.85 & $0.12 b$ & 0.39 & $0.51 b$ & 0.11 & 9.14 \\
\hline Chiseling & 33.10a & 1.27 & 0.82 & $0.16 a$ & 0.39 & $0.55 a$ & 0.13 & 9.61 \\
\hline Conventional Tillage & $34.40 a$ & 1.29 & 0.84 & $0.12 b$ & 0.39 & $0.51 b$ & 0.13 & 9.73 \\
\hline CV (\%) & 10.46 & 3.40 & 3.73 & 25.35 & 7.70 & 3.66 & 9.32 & 16.70 \\
\hline $\mathrm{F}$ & $7.13^{*}$ & $1.68^{\text {ns }}$ & $1.73^{\text {ns }}$ & $3.84^{*}$ & $0.14^{\mathrm{ns}}$ & $11.53^{*}$ & $0.61^{\mathrm{ns}}$ & $0.12^{\text {ns }}$ \\
\hline \multicolumn{9}{|c|}{$0.20-0.30 \mathrm{~m}$} \\
\hline No-tillage & $26.23 b$ & 1.27 & $0.82 a$ & $0.13 b$ & 0.39 & $0.52 b$ & $0.13 a$ & $7.25 a b$ \\
\hline Chiseling & $29.37 a$ & 1.20 & $0.78 b$ & $0.16 a$ & 0.39 & $0.55 a$ & $0.12 \mathrm{a}$ & $8.30 a$ \\
\hline Conventional Tillage & $26.20 \mathrm{~b}$ & 1.23 & $0.80 a b$ & $0.11 b$ & 0.40 & $0.51 b$ & $0.08 b$ & $7.11 b$ \\
\hline CV (\%) & 5.08 & 5.26 & 4.69 & 20.22 & 6.51 & 4.89 & 22.08 & 7.30 \\
\hline $\mathrm{F}$ & $15.51^{*}$ & $2.33^{\text {ns }}$ & $2.99^{*}$ & $9.26^{*}$ & $0.80^{\text {ns }}$ & $5.87^{*}$ & $1.99^{*}$ & $4.25^{*}$ \\
\hline
\end{tabular}

ns, no significant difference. Means followed by equal letters do not differ by the Duncan test at $5 \%$ probability. CV = coefficient of variation

agreement with the results obtained in the $0.05-0.10$ and 0.10-0.20 $\mathrm{m}$ layers in the chiseling and conventional tillage treatments. The tillage effect on increasing TOC in depth is evident in the 0.20-0.30 m layer, since the TOC levels in the no-tillage and conventional tillage treatments were similar.

The increase in TOC has a direct influence on the physical attributes of the soil. In soils of the southern region of Brazil, TOC levels of $15-30 \mathrm{~g} \mathrm{dm}^{-3}$ are considered good soil quality indicators (CQFS-RS/SC, 2004; Nascimento et al., 2018). The TOC content between $15-50 \mathrm{~g} \mathrm{dm}^{-3}$ are indicative of soil with excellent physical quality (Reynolds et al., 2009; Nascimento et al., 2018). In this context, the results indicated that all the treatments presented optimal soil physical quality at all depths studied. According to Costa et al. (2015), ICLS systems may present higher TOC levels in relation to agricultural systems because forages produce large amounts of biomass and root volume. The authors emphasize that the presence of animal waste also favors TOC supply.

The no-tillage treatment presented the highest $\rho_{B}$ in the 0.00-0.05 and 0.05-0.10 m layers in relation to the Chiseling and Conventional tillage treatments, most likely due to the reduction (although not significant) of the total porosity and the structural index in conjunction with the TOC contribution in structuring the soil, directly affecting $\rho_{B}$ (Table 2). According to Drescher et al. (2016) and Reichert et al. (2017) high $\rho_{B}$ in no-tillage systems is due to soil restructuring which occurs due to the natural arrangement of the particles and the wetting and drying cycles of the soil. The chiseling effect on reducing the $\rho_{B}$ of the Ferralsol could be detected after twelve months of its implementation in the $0.00-0.05 \mathrm{~m}$ and $0.05-0.10 \mathrm{~m}$ layers. According to Rosa et al. (2008), the effect of chiseling on the physical attributes of the soil is more evident in the topsoil layers, decreasing with the increase in time since the treatment. The authors concluded that the effect of chiseling on the physical attributes of a Rhodic Ferralsol under crop use lasted for up to four years. Moreover, Drescher et al. (2016) stated that the chiseling effect was detected for up to two and a half years in a Rhodic Ferralsol under crop use.

Several authors have reported the ephemeral effect of chiseling on soil physical attributes. Rosa et al. (2008) detected the effects for up to four years in a clayey Rhodic Ferralsol with crop succession. Drescher et al. (2016) observed effects two and a half years after management in a clayey Ferralsol conducted under crop rotation. Colussi et al. (2014) observed that chiseling of a very clayey Nitosol could be detected after nine months. Reichert et al. (2017) reported that the effects on a medium-textured Red-Yellow Acrisols under crop succession were no longer detected after nine months of management.

Chiseling has an immediate effect on improving the physical quality of the soil (Drescher et al., 2016; Calonego et al., 2017). However, this effect does not last for more than one year (Colussi et al., 2014; Calonego et al., 2017; Reichert et al., 2017). From this period on the improvement of the physical quality is attributed to the coverage plants maintained in the soil resulting from the no-tillage system (Calonego et al., 2017). In this experiment the determinations occurred one 
year after the chiseling, showing benefits of this management in improving the physical attributes of the soil. The succession of ryegrass crops under continuous no-tillage did not have a similar effect to chiseling in improving the physical quality of the Rhodic Ferralsol. The result is explained by the absence in diversity of root systems in the soil, since the species used in this work are grasses. It is known that grasses have a primordial effect on soil structuring due to improved aggregation (Seben Júnior et al., 2016). However, diversified cover crops must be adopted to improve the soil physical quality; in this context legume insertion could improve the structural quality of the soil under no-tillage because their root system favors forming macropores (Seben Junior et al., 2016; Calonego et al., 2017; Reichert et al., 2017). Crop diversification is necessary for chiseling to be an effective management of the area.

High $\rho_{B}$ values are common in soils under no-tillage in ICLS systems. The high $\rho_{B}$ values in this experiment can be attributed to the action of machine traffic, animal trampling and the absence of crop rotation. Drescher et al. (2016) observed a higher $\rho_{B}$ value in a clayey Rhodic Ferralsol under crop use in no-tillage treatment conducted 16 years ago in relation to the chiseling system every two and a half years, both using crop rotation management systems of: wheat, soybean, vetch (Vicia sativa L.), corn, white oats (Avena sativa L.) and soybeans. However, according to Reichert et al. (2017) only the $\rho_{B}$ value does not allow to infer that the adopted management causes soil compaction. Thus, other more sensitive attributes to compaction should be taken into account in order to evaluate the impacts of the management system on the physical quality of the soil, such as hydraulic conductivity (Allmaras et al., 1977; Drescher et al., 2016), aggregation (Calonego et al., 2017), penetration resistance (Drescher et al., 2016; Colussi et al., 2014; Reichert et al., 2017) and the compaction degree (Rossetti and Centurion, 2015; Drescher et al., 2016; Sá et al., 2016).

There was an effect of the treatments in altering the $\rho_{R}$ of the studied soil, which evaluates the soil compaction degree (Rossetti \& Centurion, 2015; Drescher et al., 2016; Sá et al., 2016). The $\rho_{R}$ determined under the conditions of this experiment is above the 0.80 limit considered critical for most crops (Beutler at al., 2005; Sá et al., 2016). However, in notillage systems the $\rho_{R}$ value considered as critical can be up to 0.90 due to the structural conditions that this system imposes on the soil (Rossetti \& Centurion, 2015). Rossetti \& Centurion (2015) evaluated the corn yield in a medium-textured Rhodic Ferralsol in no-tillage systems with different implantation times and observed $\rho_{R}$ values $>0.87$, where the authors did not observe a reduction in crop yield. In addition, Sá et al. (2016) concluded that $\rho_{R}>0.88$ limited the root growth of mechanized sugarcane (Saccharum officinarum) in a very clayey acric Rhodic Ferralsol under no-tillage. Furthermore, $\rho_{R}$ values $>0.77$ under conventional tillage do not compromise crop yield (Beutler et al., 2005).

The results indicate that treatments significantly affected the soil compaction degree in the $0.05-0.10$ and $0.20-0.30 \mathrm{~m}$ layers (Table 3 ). The effect of chiseling on reducing the sub- surface compaction degree is attributed to the working depth of the implemented chiseling rod $(\approx 0.30 \mathrm{~m})$ (Drescher et al., 2016). Increasing the degree of compaction usually results in a reduction in soil aeration, meaning in the macropore volume (MA). In this sense, the reduced compaction degree in the chiseling was accompanied by an increase of the MA, and not only in the 0.05-0.10 and 0.20-0.30 m layers, but it was also significant for the $0.10-0.20 \mathrm{~m}$ layer. Rossetti \& Centurion (2015) observed MA $<0.10 \mathrm{~m}^{3} \mathrm{~m}^{-3}$, which limits root growth (Lapen et al., 2004; Reynolds et al., 2009) in a medium texture Ferralsol when the $\rho_{R}$ value exceeded 0.89; a condition that was not determined in this work.

The chiseling MA volume was higher than the no-tillage and conventional tillage treatments in the $0.05-0.10,0.10-0.20$ $\mathrm{m}$ and 0.20-0.30 $\mathrm{m}$ layers. Therefore, the effect of chiseling on increasing MA was more evident in sub-surface layers of the Ferralsol after 12 months of management. Contrary to these results, Rosa et al. (2008) verified that a chiseling every two or four years of a clayey Rhodic Ferralsol under crop rotation was efficient in increasing the MA in the topsoil $(0.00-0.10 \mathrm{~m})$. However, the authors did not observe chiseling effect on the subsurface layers. In addition, the authors emphasize that the chiseling effect on the MA of topsoil layers can be detected up to four years after management.

Chiseling and conventional tillage did not have effect in promoting significant differences in the MA in the 0.00-0.05 $\mathrm{m}$ layer, in relation to no-tillage, indicating that these tillage operations have no effect in providing significant differences in macroporosity of soils under ICLS. Due to the soil disruption provided by the treatments on the particle arrangement and the soil structure when being trampled by cattle, the particles were more easily compressed, thus reducing MA (Drescher et al., 2016; Reichert et al., 2017). It is worth mentioning that the MA volume determined in the conditions of this experiment is above the value considered critical for satisfactory root development, which is $0.10 \mathrm{~m}^{3} \mathrm{~m}^{-3}$ (Lapen et al., 2004; Reynolds et al., 2009).

The increase in the chiseling MA yielded significantly higher results in total porosity (TP) in the $0.10-0.20$ and $0.20-0.30 \mathrm{~m}$ layers in relation to no-tillage and conventional tillage. The effect of the conventional treatment on TP was not detected after six months of operations.

There were no significant differences between the treatments in the soil structure evaluated by the structural index (SI). The SI values up to the depth of $0.20 \mathrm{~m}$ are above the $9 \%$ value indicative of soils with stable structure (Reynolds et al., 2009; Ghiberto et al., 2015). The SI in the 0.20-0.30 $\mathrm{m}$ layer was statistically different between the treatments, where the Chiseling was the best. The reduced $\mathrm{SI}$ at depth is attributed to the lower proportion of TOC in deeper layers and the increase in clay content in the $0.20-0.30 \mathrm{~m}$ layer (Ghiberto et al., 2015). However, despite the significant differences in this layer, the SI values provided by the treatments are above $7 \%$, which indicates soils with a low risk of physical degradation (Reynolds et al., 2009; Ghiberto et al., 2015). 
The WA content in all treatments in the 0.00-0.05 m layer is almost $0.15 \mathrm{~m}^{3} \mathrm{~m}^{-3}$, which is a value considered optimal for plant development (Reynolds et al., 2009). The best WA condition observed in the 0.00-0.05 $\mathrm{m}$ layer is explained by the higher TOC content in this layer, which favors water retention in the soil. Thus, even if drier conditions occur in the region, the adopted treatments would have the potential to maintain crop productivity. However, the treatments in the subsequent layers provided $W A<0.15 \mathrm{~m}^{3} \mathrm{~m}^{-3}$, indicating that there may be productivity damage due to a lack of water in drought conditions (Reynolds et al., 2009; Nascimento et al., 2018).

The penetration resistance (PR) values determined in the field capacity condition $(\psi=-100 \mathrm{hPa}$ ) are presented in Figure 1. The highest PR value in the more superficial layers of $0.00-0.05$ and $0.05-0.10 \mathrm{~m}$ was verified in the notillage treatment and the lowest in the chiseling, while the conventional treatment was intermediate, and not differing from the chiseling; from $0.10 \mathrm{~m}$ there was an inversion of the mean values of PR between no-tillage and conventional tillage, with these being statistically equal and both greater than the chiseling treatment. The increase in PR in the 0.10$0.20 \mathrm{~m}$ layer in conventional tillage is attributed to compaction below the working depth of the equipment such as harrowers and plows. The chiseling effect on PR could be detected up to a depth of $0.20 \mathrm{~m}$, even after 12 months of management. Drescher et al. (2016) reported that PR is the best parameter to evaluate the effects of chiseling on soil physical attributes, which is more sensitive to changes in $\rho_{B}$ and porosity.

The highest PR values in the no-tillage layers are attributed to the absence of tilling in this treatment, which maintains the stronger cohesion between the soil particles (Piva et al., 2012). The critical PR value for crop growth may be variable depending on the soil, the adopted management system and/ or cultivated crops. Thus, the PR values determined in this work are below that proposed by Moraes et al. (2014b) as limiting for the root growth of a clayey Ferralsol, which is: 3.5 MPa no-tillage with crop rotation; 3.0 for chiseling systems, and to maintain 2.0 $\mathrm{MPa}$ as the limiting value in conventional treatment, which is recurrent in the literature (Tormena et al., 1998; Moraes et al., 2014b).

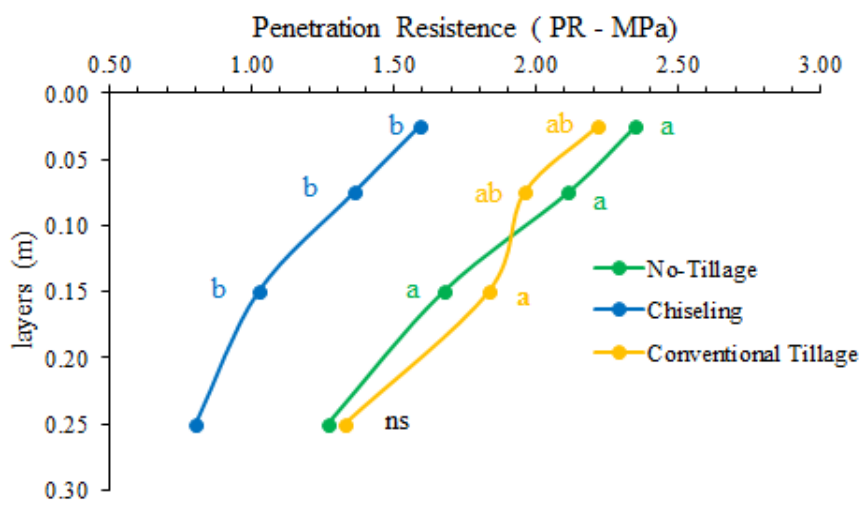

ns, no significant difference. Means followed by equal letters do not differ by Duncan test at $5 \%$ probability.

Figure 1. Resistance to root penetration (PR) determined under field capacity conditions of a Ferralsol under croplivestock integration, with different soil tillage.
There were no significant differences in corn silage yield or in the supply of ryegrass forage in the $2013 / 14$ crop in the Ferralsol (Figure 2). The absence of significant difference is attributed to a good distribution of rain during the crop's growing phases and to the soil's good physical quality. Another factor that favored high silage yields was fertilization, since $\mathrm{N}$ and $\mathrm{K}$ are the primordial nutrients for silage yield (Costa et al., 2015), as they are linked to shoot growth and development. The average corn silage yield in the Castro-PR-Brazil region is about $10,000 \mathrm{~kg} \mathrm{ha}^{-1}$ of DM (dry matter) and for grazed ryegrass is about $2,500 \mathrm{~kg} \mathrm{ha}^{-1}$ of DM (Moraes et al., 2014a). Fertilization was performed aiming at high silage yield, and there were no effects of treatments on yield because the soil's physical conditions were not impeding to plant development.

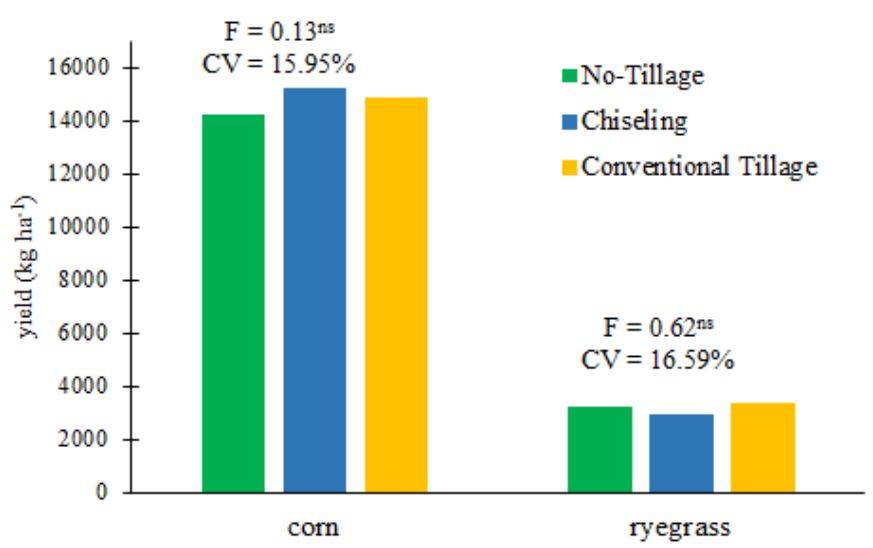

$\mathrm{CV}=$ coefficient of variation. ${ }^{\mathrm{ns}}$, no significant difference.

Figure 2. Dry matter yield of maize and ryegrass in the crop year 2013/14.

\section{Conclusions}

Chiseling did not provide higher corn silage and ryegrass yield under crop-livestock integration compared to other treatments.

Chiseling carried out every two years provided improvements in the physical attributes of the Ferralsol conducted over nine years under crop-livestock integration, with chiseling effects on the soil physical attributes detected 12 months after the management.

\section{Literature Cited}

Allmaras, R.R.; Rickman, R.W; Ekin, L.G; Kimbal, B.A. Chiseling Influences on Soil Hydraulic Properties. Soil Science Society of America Journal, v. 41, n. 4, p. 796-803, 1977. https://doi. org/10.2136/sssaj1977.03615995004100040039x.

Alvares, C.A.; Stape, J.L.; Sentelhas, P.C.; Gonçalves, J.L.M.; Sparovek, G. Köppen's climate classification map for Brazil. Meteorologische Zeitschrift v. 22, n. 6, p. 711-728, 2013. https:// doi.org/10.1127/0941-2948/2013/0507.

Beutler, N.A.; Centurion, J.F.; Roque, C.G.; Ferraz, M.V. Densidade relativa ótima de Latossolos Vermelhos para a produtividade de soja. Revista Brasileira de Ciência Solo, v.29, n.6, p.843-849, 2005. https://doi.org/10.1590/S0100-06832005000600002. 
Calonego, J.C.; Raphael, J.P.A.; Rigon, J.P.G.; Oliveira Neto, L.; Rosolem, C.A. Soil compaction management and soybean yields with cover crops under no-till and occasional chiseling. European Journal of Agronomy, v.85, p.31-37, 2017. https://doi.org/10.1016/j. eja.2017.02.001.

Colussi, G.; Silva, L.S.; Minato, E.A. Escarificação e adubação orgânica: efeito na recuperação estrutural de solo produzindo Tifton 85. Ciência Rural, v.44, n.11, p.1956-1961, 2014. https:// doi.org/10.1590/0103-8478cr20131670.

Comissão de Química e Fertilidade do Solo RS/SC - CQFS-RS/SC. Recomendações de adubação e de calagem para os estados do Rio Grande do Sul e de Santa Catarina. 3.ed. Passo Fundo: Sociedade Brasileira de Ciência do Solo; CQFS-RS/SC, 2004. 400p. http://www.sbcs-nrs.org.br/docs/manual_de_adubacao_2004_ versao_internet.pdf. 18 Jan. 2019.

Costa, N.R.; Andreotti, M.; Samejima, K.; Lopes, M.; Yokobatake, L.; Ferreira, J.P.; Pariz, C.M.; Atributos do Solo e Acúmulo de Carbono na Integração Lavoura-Pecuária em Sistema Plantio Direto. Revista Brasileira de Ciência Solo, v.39, n.1, p.852-863, 2015. https://doi.org/10.1590/01000683rbcs20140269.

Drescher, M.S.; Reinert, D.J.; Denardin, J.E.; Gubiani, P.I.; Faganello, A.; Drescher, G.L. Duração das alterações em propriedades físico-hídricas de Latossolo argiloso decorrentes da escarificação mecânica. Pesquisa Agropecuária Brasileira, v.51, n.2, p.159-168, 2016. https://doi.org/10.1590/S0100-204X2016000200008.

Ghiberto, P.J.; Imhoff, S.; Libardi, P.L.; Silva, A.P.; Tormena, C.A.; Pilatti, M.A. Soil physical quality of Mollisols quantified by a global index. Scientia Agrícola, v.72, n.2, p.167-174, 2015. https://doi. org/10.1590/0103-9016-2013-0414.

Kunz, M.; Gonçalves, A.D.M.A.; Reichert, J.M.; Guimarães, R.M.L.; Reinert, D.J.; Rodrigues, M.F. Compactação do solo na integração soja-pecuária de leite em Latossolo argiloso com semeadura direta e escarificação. Revista Brasileira de Ciência Solo, v.37, n.6, p.1699-1708, 2013. https://doi.org/10.1590/S010006832013000600026.

Lapen, D.R.; Topp, G.C.; Gregorich, E.G.; Curnoe, W.E. Least limiting water range indicators of soil quality and corn production, eastern Ontario, Canada. Soil and Tillage Research, v.7, v.2, p.151-170, 2004. https://doi.org/10.1016/j.still.2004.02.004.

Lozano, L.A.; Soracco, C.G.; Villarreal, R.; Ressia, J.M.; Sarli, G.O.; Filgueira, R.R. Soil physical quality and soybean yield as affected by chiseling and subsoiling of a no-till soil. Revista Brasileira de Ciência Solo, v.40, n.1, p.1-12, 2016. https://doi.org/10.1590/18 069657 rbcs20150160.

Marcolin, C.D.; Klein, V.A. Determinação da densidade relativa do solo por uma função de pedotransferência para a densidade do solo máxima. Acta Scientiarum. Agronomy, v.33, n.2, p.349-54, 2011. https://doi.org/10.4025/actasciagron.v33i2.6120.

Moraes, A. de; Carvalho, P.C. de.F.; Anghinoni, I.; Brasil, S.; Lustosa, C.; Costa, S.E.V.G.; Kunrath, T.S. Integrated crop - livestock systems in the Brazilian subtropics. European Journal of Agronomy, v.57, p.4-9, 2014a. https://doi.org/10.1016/j.eja.2013.10.004.

Moraes, M.T. de; Debiasi, H.; Carlesso, R.; Franchini, J.C.; Silva, V.R. da. Critical limits of soil penetration resistance in a Rhodic Eutrudox. Revista Brasileira de Ciência Solo, v.38, n.1, p.288-98, 2014b. https://doi.org/10.1590/S0100-06832014000100029.
Nascimento, D.M.; Cavalieri-Polizeli, K.M.V.; Silva, A.H.; Favaretto N.; Parron, L.M. Soil physical quality under long-term integrated agricultural production systems. Soil \& Tillage Research, v.186, n.8, p.292-299, 2019. https://doi.org/10.1016/j.still.2018.08.016.

Olson, K.R.; Al-Kaisi, M.; Lal, R.; Cihacek, L. Soil Organic Carbon Dynamics in Eroding and Depositional Landscapes. Open Journal of Soil Science, v.6, n.8, p.121-134, 2016. https://doi. org/10.4236/ojss.2016.68013.

Piano, J.F.; Oliveira, P.S.R.; Costa, P.F.; Taffarel, L.E.; Egewarth, J.F.; Castagnara, D.D.; Borsoi, A.; Egewart, V.A. Soil physical attributes under different grazing management of winter forage crops in crop-livestock system at Southern Brazil. African Journal of Agricultural Research, v.10, n.3, p.146-153, 2015. https://doi. org/10.5897/AJAR2014.8943.

Piva, J.T.; Dieckow, J.; Bayer, C.; Zanatta, J.A.; de Moraes, A.; Pauletti, V.; Tomazi, M.; Perger, M. No-till reduces global warming potential in a subtropical Ferralsol. Plant and Soil, v.361, n.1-2, p.359-373, 2012. https://doi.org/10.1007/s11104-012-1244-1.

Prevedello, C.L.; Loyola, J.M.T. Modelo para estimar as propriedades hidráulicas de meios porosos a partir da curva granulométrica. In: Congresso Brasileiro de Mecânica dos Solos e Engenharia Geotécnica, 12., São Paulo, 2002. Anais... São Paulo: ABMS, 2002. p. 467-472.

Reichert, J.M; Brandt, A.A.; Rodrigues, M.F.; da Veiga M.; Reinert, D.J. Is chiseling or inverting tillage required to improve mechanical and hydraulic properties of sandy clay loam soil under longterm no-tillage? Geoderma. v.301, p.72-79, 2017. https://doi. org/10.1016/j.geoderma.2017.04.012.

Reynolds, W.D.; Drury, C.F.; Tan, C.S.; Fox, C.A.; Yang, X.M. Use of indicators and pore volume-function characteristics to quantify soil physical quality. Geoderma, v.152, p.252-263, 2009. https:// doi.org/10.1016/j.geoderma.2009.06.009.

Richards, L.A. Physical conditions of water in soil. In: Black, C.A. (Ed.). Methods of soil analysis. Part 1. Madison: American Society for Testing and Materials, 1965. 770p. (Series. Agronomy, 9).

Rosa, D.P.; Reichert, J.M.; Sattler, A.; Reinert, D.J.; Mentges, M.I.; Vieira, D.A. Relação entre solo e haste sulcadora de semeadora em Latossolo escarificado em diferentes épocas. Pesquisa Agropecuária Brasileira, v.43, n.3, p.395-400, 2008. https://doi. org/10.1590/S0100-204X2008000300015.

Rossetti, K.V.; Centurion, J.F. Ensaio de compactação em Latossolo cultivado com milho sob diferentes períodos de adoção de tipos de manejo. Revista Brasileira de Ciências Agrárias, v.10, n.4, p.499-505, 2015. https://doi.org/10.5039/agraria.v10i4a5013.

Sá, M.A.C.; Santos Junior, J.D.G.; Franz, C.A.B.; Rein, T.A. Qualidade física do solo e produtividade da cana-de-açúcar com uso da escarificação entre linhas de plantio. Pesquisa Agropecuária Brasileira, v.51, n.9, p.16101622, 2016. https://doi.org/10.1590/s0100-204×2016000900061.

Santos, H.G.; Jacomine, P.K.T.; Anjos, L.H.C.; Oliveira, V.A.; Lumbreras, J.F.; Coelho, M.R.; Almeida, J.Á.; Araújo Filho, J.C.; Oliveira, J.B.; Cunha, T.J.F. Brazilian soil classification system. 5.ed. Brasília: Embrapa, 2018a. http://ainfo.cnptia.embrapa.br/digital/ bitstream/item/181678/1/SiBCS-2018-ISBN-9788570358219english.epub. 10 Jan. 2019.

Santos, J.A.; Ferreira, A.; Barth, G. Silage maize quality in different uses of Italian ryegrass and soil management methods after liming. Archives of Agronomy and Soil Science, v.64, n.2, p.173184, 2018b. https://doi.org/10.1080/03650340.2017.1338832. 
Seben Junior, G.F.; Corá, J.E.; Lal, R. Soil aggregation according to the dynamics of carbon and nitrogen in soil under different cropping systems. Pesquisa Agropecuária Brasileira, v.51, n.9 p.1652-1659, 2016. https://doi.org/10.1590/s0100-204×2016000900065.

Shahbaz. M.; Kuzyakov, Y.; Heitkamp, F. Decrease of soil organic matter stabilization with increasing inputs: Mechanisms and controls. Geoderma, v.304, p.76-82, 2017. https://doi.org/10.1016/j. geoderma.2016.05.019.

Silva, A.C.; Armindo, R.A.; dos Santos, B.A.; Schaap, M.G. SPLINTEX: A physically-based pedotransfer function for modeling soil hydraulic functions. Soil and Tillage Research, v.174, p.261-272, 2017. https://doi.org/10.1016/j.still.2017.07.011.
Tormena, C.A.; Silva, A.P.; Libardi, P.L. Caracterização do intervalo hídrico ótimo de um Latossolo Roxo sob plantio direto. Revista Brasileira de Ciência Solo, v.22, n.4, p.573-581, 1998. https://doi. org/10.1590/S0100-06831998000400002.

van Genuchten, M.T. A closed-form equation for predicting the hydraulic conductivity of unsaturated soils. Soil Science Society of America Journal, v.44, p.892-898, 1980. https://doi.org/10.2136/ sssaj1980.03615995004400050002x.

Walkley, A.; Black, I.A. An examination of the Degtjareff method for determining soil organic matter and a proposed modification of the chromic acid titration method. Soil Science. v. 37, n.1, p. 2938, 1934. https://doi.org/10.1097/00010694-193401000-00003. 